\title{
NOTICIAS
}

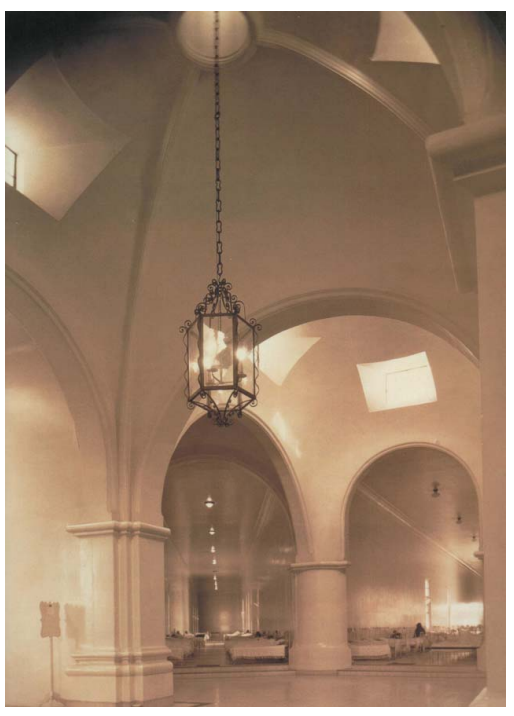

Ignacio Gómez Gallardo. Hospital Civil. Ca. 1940 Colección Oskar Ruizesparza.

Tomada de: Artes de México, número 4l.

\section{El legado de Fray Antonio Alcalde}

Discurso pronunciado con motivo dela entrega del Premio Fray Antonio Alcalde durante el "Segundo Congreso de Gestión de la Calidad en Salud", celebrado en Guadalajara, Jalisco, en el mes defebrero de 2003.

El notable historiador tapatío Luis Pérez Verdía informó hace 100 años que apenas se apagara el estruendo de los combates que sepultaron, al parecer para siempre, los derechos indígenas ante la fuerza brutalmente armada y legitimada por los podero- sos intereses políticos de la España de los siglos XVI y XVII, la violencia en nuestro continente fue erigida en un sistema que arrebató a millones de indios su libertad, su propiedad y su dignidad primero, y hasta su propia vida después.

Agrego yo ahora que más intenso que el estruendo de la lucha y el fragor de las armas, extendido desde la Provincia del Pánuco, bañada por el precioso golfo mexicano y el Amazonas, hasta Centispac y Cuzco, en la vecindad del azulísimo Pacífico surgió un espantoso quejido de servidumbre. $Y$ es que la crueldad y la codicia de los conquistadores no tenía límites: cambiaban una yegua por 20 indios esclavos o un hombre libre por un queso. Hubo además una conquista erótica y violenta de nuestras tierras en donde un solo soldado español podía violar impunemente a 30 o 40 jovencitas indígenas y procrear hijos que luego abandonaba.

Los dolorosísimos lamentos y los gemidos de los millones de oprimidos finalmente encontraron eco en el Viejo Mundo, de manera que los franciscanos primero y los dominicos después vinieron, muchas décadas más tarde, a enjugar manantiales de lágrimas de indios y a consolar tantísimo horror y sangre derramados por el filo de las espadas españolas.

Luego, cuando a finales del siglo XVIII las múltiples epidemias de la Guadalajara de Indias cubrieron de muertos todas las casas y todas las calles de la ciudad, las celdas de los monjes betlemitas y los camposantos de los templos, el dominico español Fray Antonio Alcalde, vigésimo segundo obispo de la Nueva Galicia, radicado aquí desde los 70 años de edad, comenzó a construir, el 6 de marzo de 1787, el grandioso hospital donde con cierto rubor declaro que he tenido la oportunidad y orgullo de trabajar ininterrumpidamente por los últimos 45 años, intentando contribuir a reducir los males de centenares de enfermos, gravísimos en su mayoría y pobres de solemnidad.

El hospital de Fray Antonio Alcalde fue terminado totalmente el 14 de junio de 1792, cuando la salud del munificentísimo Obispo era ya muy frágil, agobiado por la edad y por tantas penitencias y ayunos. Finalmente, 55 días más tarde, a las cuatro de la mañana del martes 7 de agosto de 1792, Fray Antonio Alcalde falleció a los 91 años, cuatro meses y 23 días de haber nacido el 14 de marzo de 1701 en la Villa de Cigales, provincia de Valladolid, en Castilla la Vieja, en España. Cuando murió Fray Antonio Alcalde, Guadalajara tenía 24249 habitantes. El hospital había costado 265120 pesos y tenía un cupo cercano a las 1000 camas.

El día de su fallecimiento la Campana Mayor de Catedral comen- 
zó su lúgubre tañir cada cuarto de hora por 100 veces, culminando en un redoble general de todas y cada una de las campanas de toda la ciudad durante una hora, para anunciarle al pueblo que había entregado su alma a Dios el anciano que durante los 21 años que vivió entre nosotros fundó la Universidad de Guadalajara, la primera imprenta, el Real Consulado de Comercio, 100 industrias de artefactos de algodón, el Santuario de Nuestra Señora de Guadalupe, el Beaterio de Santa Clara y el Sagrario Metropolitano. Pero sobre todo fundó la instrucción primaria para los indios, en una época en que educar a los pobres era sacudirles sus grilletes de sumisión y prepararlos para la independencia nacional.

El cuerpo de Fray Antonio Alcalde duerme en el Santuario de la Virgen de Guadalupe; su memoria vive en todos nosotros. Según el poeta Gutiérrez Nájera, el Alma de Fray Antonio Alcalde no quiso entrar al cielo porque no pudiera haber sido dichoso entre los dichosos. Está invisible todo tiempo en el Hospital de Belén, musitando latines de ternura y de esperanza a los pobrecitos en- fermos que por no poseer nada, todo merecen.

Es magnífico que se otorguen reconocimientos con el nombre de su ilustrísima no sólo a la calidad de los servicios como ruta para alcanzar la excelencia académica en la atención a los dolientes, sino igualmente y sobre todo a la caridad, la ternura y la esperanza que les debemos a todos ellos, especialmente a los más desamparados. La caridad fue, sin duda, la más notoria de todas las virtudes de Fray Antonio Alcalde. Caridad concreta, aplicada, útil, para satisfacer tanto las necesidades materiales como las espirituales de los enfermos. Caridad en forma de consuelo o traducida en forma de limosnas. Moribundos, viudas pobres, hambrientos, niños desnutridos, obreros sin empleo, intelectuales indigentes y sobre todo enfermos pobres, todos encontraron en Fray Antonio un corazón grande y una mente abierta.

Fue la caridad cristiana la que determinó que en su hospital todos los enfermos fueran atendidos sin costo. Ojalá y la calidad y la gratitud fueran concomitantes y permanentemente aseguradas, como lo hizo en su época Fray Antonio Alcal- de y como lo podrían hacer ahora los dineros de los gobiernos federal y estatal para que los directivos de mi Hospital de Belén no se vieran obligados a pedir continuamente cuotas de recuperación a los que nada tienen.

Deseo ahora expresar mi permanente gratitud a los directores de $\mathrm{mi}$ hospital, y a mi brillante y personal amigo Héctor Gallardo Rincón por haberme obsequiado este espacio que prologa la entrega de los premios con el nombre de Fray Antonio Alcalde, sin duda el más señero de los habitantes que jamás haya tenido Jalisco, y autor de toda su grandeza.

Termino comprometiéndome ante la amable presencia de todos ustedes a que mientras la vida me acompañe seguiré transitando los caminos que nuestro pueblo pobre recorre en su búsqueda incansable de pan, agua, luz, seguridad, justicia, un poco de educación y de salud gratuita, y un poco de felicidad, que fue en su conjunto el legado que Fray Antonio Alcalde nos dejó hace 210 años. 